\title{
Potential Analgesic Activity of Root Extract of Operculina turpethum Linn.
}

\author{
Jai Parkash Kadian*1, Amrendra Kr Chaudhary², Bhupendra Chauhan ${ }^{3}$, Ranjit Singh ${ }^{4}$ \\ 1. Associate Professor, Adarsh Vijendra Institute of Pharmaceutical Sciences, Shobhit University, Gangoh, Saharanpur, UP, India. \\ 2. Assistant Professor, Department of Pharmacy, LLRM Medical College, Meerut, UP, India. \\ 3. Associate Professor, Adarsh Vijendra Institute of Pharmaceutical Sciences, Shobhit University, Gangoh, Saharanpur, UP, India. \\ 4. VC, Shobhit University, Gangoh, Saharanpur, UP, India. \\ *Corresponding author's E-mail: kadianjaiprakash6@gmail.com
}

Received: 22-06-2020; Revised: 20-09-2020; Accepted: 24-09-2020; Published on: 20-10-2020.

\section{ABSTRACT}

Currently available analgesic and anti-inflammatory agents exhibit a multiple of side-effects including hepatotoxicity and ulcer. The objective of the present study was to assess the analgesic activity of the root extract of Operculina turpethum (OT) Linn. in order to explore it as safe analgesic. The analgesic activity of the extract was evaluated using Swiss albino mice of both sexes. The animals were divided into 8 groups for acetic acid induced writhing test namely, Group I - distilled water (10 ml/kg, p.o.), Group II, III and IVmethanolic extract (50, 100 and $200 \mathrm{mg} / \mathrm{kg}$, p.o. respectively), Group V - aqueous extract ( $200 \mathrm{mg} / \mathrm{kg}$, p.o.), Group VI - Aspirin (100 $\mathrm{mg} / \mathrm{kg}$, i.p.), Group VII - Pethidine ( $25 \mathrm{mg} / \mathrm{kg}$, i.p.), Group VIII - methanolic extract ( $200 \mathrm{mg} / \mathrm{kg}$, p.o.) + naloxone (5 mg/kg, i.p.) and into 7 groups for hot plate test namely, Group I - distilled water (10 ml/kg, p.o.), Group II, III and IV- methanolic extract (50, 100 and 200 $\mathrm{mg} / \mathrm{kg}$, p.o. respectively), Group V - aqueous extract ( $200 \mathrm{mg} / \mathrm{kg}$, p.o.), Group VI - methanolic extract (200 mg/kg, p.o.) + naloxone (5 $\mathrm{mg} / \mathrm{kg}$, i.p.), Group VII - pethidine ( $25 \mathrm{mg} / \mathrm{kg}$, i.p.). The results showed that methanolic extract of the root Operculina turpethum have significant analgesic activity at the doses of $100 \mathrm{mg} / \mathrm{kg}$ and $200 \mathrm{mg} / \mathrm{kg}$, whereas aqueous extract showed significant analgesic activity at the dose of $200 \mathrm{mg} / \mathrm{kg}$. The animal study of methanolic and aqueous root extract of Operculina turpethum showed analgesic activity through both central and peripheral mechanism.

Keywords: Analgesic, Aspirin, Naloxone, Operculina turpethum, Pethidine.

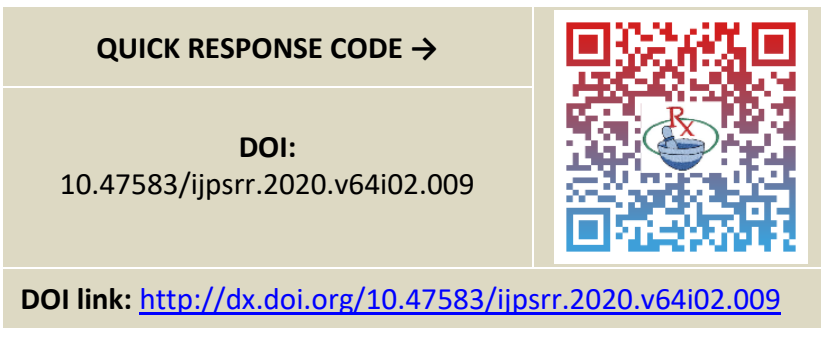

\section{INTRODUCTION}

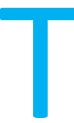

he plant Operculina turpethum Linn., belonging to the family Convolvulaceae, is a source of drug known as Indian jalap or turpeth. It is a perennial climber with latex. Root is long cylinder, fleshy and much branched. Stems are very long, fast growing, twining and much twisted, angled and winged. The active principle of the plant Operculina turpethum is a glycoside resin present in the drug up to $10 \%$ and is similar to jalap resin which is concentrated mostly in the root bark. Ether insoluble glycoside, turpethin, which constitutes about half of the resin and two ether soluble glycosides, alpha and beta turpethein are also present in it. The plant parts viz. root, root bark and stem are used traditionally for the treatment of different diseases. The root of Operculina turpethum has been used since ancient days in Ayurvedic medical practice for the treatment of various disorders. The roots are bitter, acrid, sweet, thermogenic, purgative, carminative, anthelmintic, expectorant, antipyretic, stimulant and hydragogue. They are useful in colic constipation, dropsy, paralysis, myalgia, arthralgia, pectoralgia, bronchitis, obesity, helminthiasis, gastropathy, inflammations, intermittent fever, leucoderma, pruritus, ulcers, erysipelas, haemorrhoids, tumours, jaundice, consumption and ophthalmia. ${ }^{1,2}$ The literature reports anti-cancer, ${ }^{3} \quad$ anti-ulcer, anti-inflammatory ${ }^{4}$, hepatoprotective activity ${ }^{5}$ antidiabetic activity ${ }^{6}$, antidiarrhoeal, antispasmodic, bronchodilator activity ${ }^{7}$ and laxative activity ${ }^{8}$ of various parts of the plant Operculina turpethum. However, there is not enough scientific data to support the others claims made in the ancient literature.

Allopathic drugs used as analgesic and anti-inflammatory, have many side effects like hepatotoxicity and ulcers. ${ }^{9}$ The present work was aimed to investigate analgesic activity of Operculina turpethum and to generate scientifically justified data so that an effective treatment for analgesia could be made available in which hepatotoxicity and ulcer like side effects could be minimized.

\section{MATERIALS AND METHODS}

\section{Collection and authentication of plant material}

The roots of the plant Operculina turpethum were obtained from a commercial supplier and authenticated by Dr. Anjula Pandey, Principal Scientist, National Bureau of Plant Genetic Resources (NBPGR), New Delhi, India. A voucher specimen has been deposited at the NBPGR Herbarium (NHCP/NBPGR/2009-35).

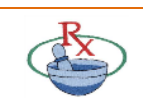




\section{Extraction}

The roots of Operculina turpethum was air dried in the shade and coarsely powdered in a grinder. The powdered material (900 g) was extracted by cold maceration with methanol. ${ }^{10}$ The powder was placed in $1500 \mathrm{ml}$ of methanol for 72 hours with constant stirring. After 72 hours, the extract was filtered and fresh methanol was added and placed for another 72 hours. Same procedure was followed 4 times. The solvent was completely removed under reduced pressure till the semi solid mass was obtained. The residue (root powder) remains after filtering the methanol extract was air dried and $300 \mathrm{~g}$ powder was weighed and successively extracted by maceration with distilled water. The extract was filtered and placed on water bath for drying. The extracts were then stored in refrigerator and weighed amount was suspended in distilled water using Tween $80(0.2 \% \mathrm{v} / \mathrm{v})$ as the suspending agent prior to administration.

\section{Animals}

Adult Swiss albino mice of either sex (20-30 g) were obtained from Indian Veterinary Research Institute, Bareilly, U.P, India. The animals were housed in polypropylene cage under standard conditions $\left(25 \pm 2{ }^{\circ} \mathrm{C}\right.$, 12 hours light and dark cycle) with free access to standard pellet feed (Ashirwad Industries, Mohali, Punjab) and water ad libitum. All the experimental procedures and protocols involving animals were reviewed by the Institutional Animal Ethical Committee (Registration number: 1279/ac/09/CPCSEA) and were in accordance with the guidelines of CPCSEA.

\section{Phytochemical testing}

Preliminary phytochemical screening of the methanolic and aqueous extracts of the roots of Operculina turpethum were performed to test the presence of the active chemical constituents such as alkaloids, glycoside, flavonoids, tannins, terpenoids, saponins, carbohydrate, protein, fixed oils and fats. ${ }^{11}$

\section{Acute toxicity study}

The Operculina turpethum root extracts were administered orally in dose of $500 \mathrm{mg} / \mathrm{kg}, 1 \mathrm{gm} / \mathrm{kg}, 2$ $\mathrm{gm} / \mathrm{kg}$ and $5 \mathrm{gm} / \mathrm{kg}$ to groups of mice $(\mathrm{n}=6)$ and percentage mortality was noted 24 hours later.

\section{Analgesic activity}

The analgesic activity of Operculina turpethum root extracts were assessed using writhing test ${ }^{12}$ and hot-plate test. ${ }^{13}$

\section{Acetic acid induced writhing model}

Mice of either sex, weighing 20-30 g, were divided into 8 groups $(n=6)$ as followings

Group I (control) - Distilled water $(10 \mathrm{ml} / \mathrm{kg}$, p.o.)

Group II, III and IV- Methanolic extract of Operculina turpethum (50, 100 and $200 \mathrm{mg} / \mathrm{kg}$, p.o. respectively)
Group V - Aqueous extract of Operculina turpethum (200mg/kg, p.o.)

Group VI - Aspirin (100mg/kg, i.p.)

Group VII - Pethidine (25mg/kg, i.p.)

Group VIII - Methanolic extract $(200 \mathrm{mg} / \mathrm{kg}$, p.o.) + Naloxone (5mg/kg, i.p.)

Acetic acid solution $(10 \mathrm{ml} / \mathrm{kg}, 0.6 \% \mathrm{v} / \mathrm{v})$ was injected intraperitoneally after $45 \mathrm{~min}$ of the administration of extract/drug and the constriction of abdominal muscles together with stretching of the hind limbs was cumulatively counted over a period of $30 \mathrm{~min}$ beginning 5 min after acetic acid injection.

Analgesic activity was expressed as the percentage inhibition of abdominal constrictions between control animals and mice pretreated with the extract using the following formula

$$
\frac{(\text { Control mean - Treated mean) }}{\text { Control mean }} \times 100
$$

In order to investigate the participation of the opioid receptor in the analgesic effect of Operculina turpethum root extracts, Group VIII animals were pretreated with non-specific opioid receptor antagonist (Naloxone, $5 \mathrm{mg} / \mathrm{kg}$, i.p), injected $30 \mathrm{~min}$ prior the administration of the extract.

\section{Eddy's hot plate model}

Mice of either sex, weight 20-30 g, were divided into 7 groups $(n=6)$ as followings

\section{Group I (control) - Distilled water (10ml/kg, p.o.)}

Group II, III and IV- Methanolic extract of Operculina turpethum (50, 100 and $200 \mathrm{mg} / \mathrm{kg}$, p.o. respectively)

Group V - Aqueous extract of Operculina turpethum (200mg/kg, p.o.)

Group VI - Methanolic extract (200mg/kg, p.o.) + Naloxone (5mg/kg, i.p.)

Group VII - Pethidine (25mg/kg, i.p.)

The hot plate test was performed to measure response latencies. The hot plate was maintained at $55.0 \pm 0.2^{\circ} \mathrm{C}$ and the animals were placed into the Perspex cylinder on the heated surface and the time (sec) to discomfort reaction (licking paws or jumping) was recorded as response latency after 30,60, 120 and 150 min after administration of the extract/ drug. A latency period of $15 \mathrm{sec}$ was defined as complete analgesia and the measurement was terminated if it exceeded the latency period in order to avoid injury. In an attempt to investigate the participation of the opioid receptor in the analgesic effect of Operculina turpethum extracts, Group VI animals were pretreated with nonspecific opioid receptor antagonist (Naloxone, $5 \mathrm{mg} / \mathrm{kg}$, i.p), injected $30 \mathrm{~min}$ prior the administration of the extract. 


\section{Statistical analysis}

The results were expressed as mean \pm standard deviation of mean (SD). The statistical analysis was carried out using ANOVA followed by Dunnett test. The level of significance was at ${ }^{*} P<0.05,{ }^{* *} P<0.01$ and ${ }^{* * *} P<0.001$ as compared to control.

\section{RESULTS}

\section{Yield of plant extract}

The root powder of Operculina turpethum weighing $900 \mathrm{~g}$ was taken for extraction with methanol which yielded $127.26 \mathrm{~g}$ of dry crude methanolic extract. The yield of methanolic extract was found to be $14.14 \% \mathrm{w} / \mathrm{w}$. The root powder of Operculina turpethum weighing $300 \mathrm{~g}$ was taken for extraction with distilled water and $61.40 \mathrm{~g}$ of dry crude aqueous extract was obtained. The yield of aqueous extract was found to be $20.50 \% \mathrm{w} / \mathrm{w}$.

\section{Phytochemical testing of Operculina turpethum Linn.}

Phytochemical testing showed that the methanolic extract of Operculina turpethum roots contains carbohydrates, glycosides, saponins, tannins and flavonoids. While aqueous extract showed the presence of carbohydrates, glycosides, saponins and tannins.

\section{Acute toxicity}

In acute toxicity study, no toxicity was noted up to the dose of $5 \mathrm{gm} / \mathrm{kg}$.

\section{Analgesic activity Models}

\section{Effect of methanolic and aqueous Operculina turpethum root extracts on acetic acid-induced writhing reflux}

Swiss albino mice were divided in to 8 groups and given different treatments. Then acetic acid $(0.6 \%, 10 \mathrm{ml} / \mathrm{kg}$, i.p.) was injected and the numbers of contraction of abdomen

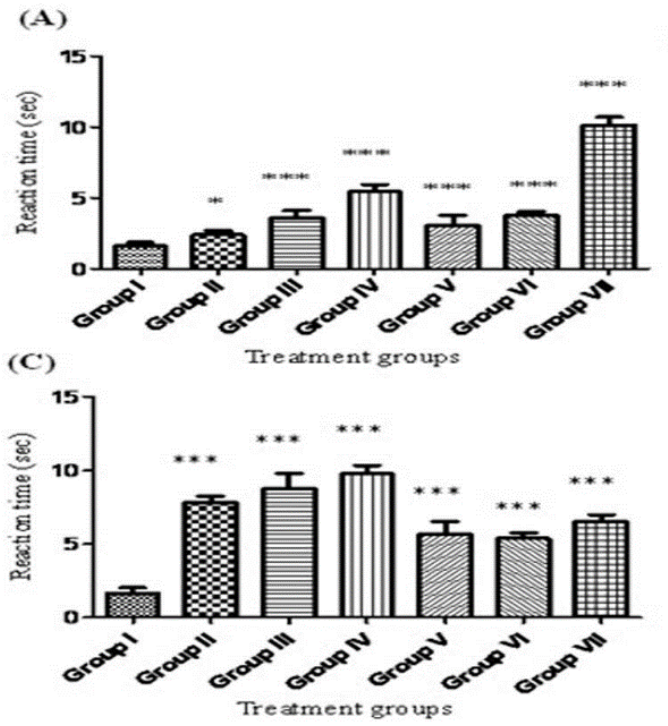

followed by stretching of hind limbs were counted for a period of $30 \mathrm{~min}$ starting after $5 \mathrm{~min}$ of the injection of acetic acid. The percentage inhibition of writhing was determined for each group (Table 1).

Table 1: Percentage inhibition of writhing in different treatment groups.

\begin{tabular}{|l|c|c|}
\hline Group & $\begin{array}{c}\text { Average number } \\
\text { of writhing }\end{array}$ & $\begin{array}{c}\% \\
\text { inhibition }\end{array}$ \\
\hline Group I (DW) & $38.67 \pm 2.16$ & - \\
\hline Group II (ME OT 50) & $35.00 \pm 3.60^{* *}$ & 9.49 \\
\hline Group III (ME OT 100) & $18.00 \pm 3.00^{* * *}$ & 53.45 \\
\hline Group IV (ME OT 200) & $8.00 \pm 1.26^{* * *}$ & 79.31 \\
\hline Group V (AE OT 200) & $17.83 \pm 1.72^{* * *}$ & 53.89 \\
\hline Group VI (Aspirin 100) & $14.00 \pm 1.79^{* * *}$ & 63.79 \\
\hline Group VII (Pethidine 25) & $2.33 \pm 1.03^{* * *}$ & 93.97 \\
\hline Group VIII (ME OT200 + & $21.50 \pm 1.87^{* * *}$ & 44.40 \\
\hline Naloxone 5) & & \\
\hline
\end{tabular}

DW = distilled water, ME OT = methanolic root extract of Operculina turpethum, AE OT = Aqueous extract of Operculina turpethum. Values are given as mean $\pm S D ; n=6$. Statistical differences between treated and control groups were evaluated by ANOVA followed by Dunnett tests. $* * \mathrm{P}<0.01, \quad * * * \mathrm{P}<0.001$ were considered significantly different as compared to control.

\section{Effects of different root extracts of Operculina turpethum on Eddy's hot plate model}

Eddy's hot plate model was used to determine the central analgesic action of extracts/drug. ${ }^{14}$ Swiss albino mice of either sex weighing 20-30 g were divided in 7 groups and placed on hot plate maintained at $55 \pm 0.2^{\circ} \mathrm{C}$ after administration of extract/ drug in different groups and reaction time i.e. jump response (in $\mathrm{sec}$ ) was recorded at $30,60,120$ and $150 \mathrm{~min}$. the results are depicted in Figure 1.

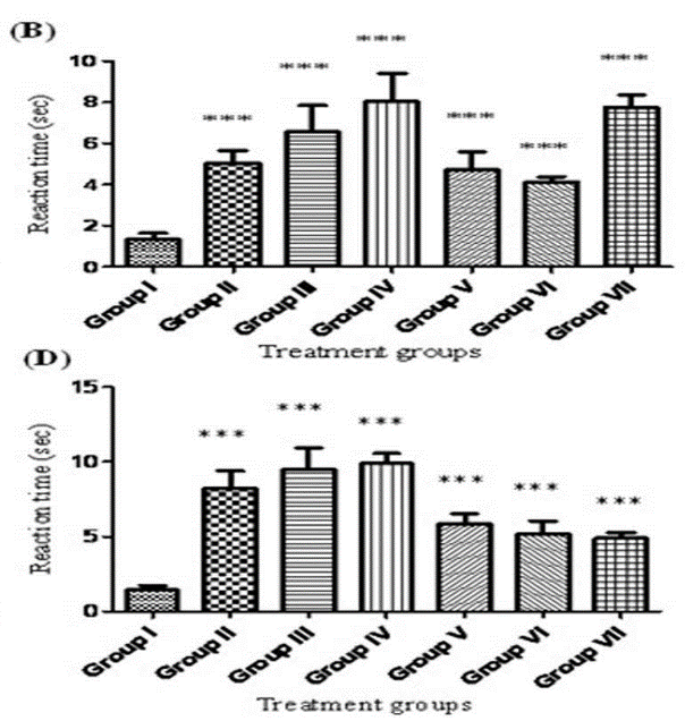

Figure 1: Analgesic effect of root extracts / drug in mice using Eddy's hot plate: (A) after 30 minutes of treatment, (B) after 60 minutes of treatment, (C) after 120 minutes of treatment, (D) after 150 minutes of treatment. Each column represents the mean reaction time (sec.) $\pm S . D(n=6)$. Statistical analysis was done by one-way ANOVA followed by Dennett's $t$-test. ${ }^{*} P<0.05$ and ${ }^{* * *} P<0.001$ were considered significantly different as compared to control. 
Effect of naloxone on the analgesic effect of methanolic root extract

Naloxone is a nonselective opioid receptor antagonist. Methanolic root extract $(200 \mathrm{mg} / \mathrm{kg}$, p.o.) showed most significant and potent analgesic effect. Group VI received methanolic extract $(200 \mathrm{mg} / \mathrm{kg}$, p.o.) 30 minutes prior to the injection of naloxone ( $5 \mathrm{mg} / \mathrm{kg}$, i.p.) and reaction time (jump response) was determined after 30, 60, 120 and 150 minuets of the naloxone injection.

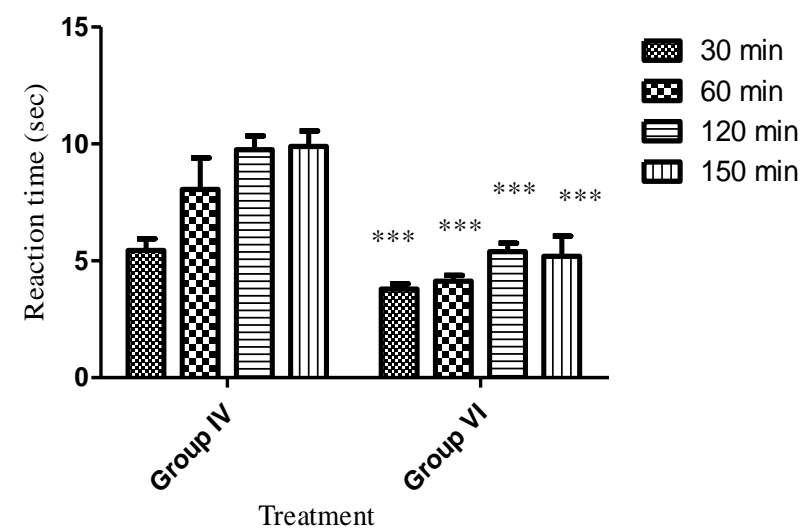

Figure 2: Comparison of analgesic effect of methanolic extract $(200 \mathrm{mg} / \mathrm{kg}$, p.o.) and methanolic root extract of
Operculina turpethum $(200 \mathrm{mg} / \mathrm{kg}$. p.o.) + Naloxone $(5 \mathrm{mg} / \mathrm{kg}$, i.p. $)$ at different time interval of treatment. Each column represents the mean reaction time (sec.) \pm S.D. Statistical analysis was done by one-way ANOVA followed by Dennett's t-test. ${ }^{* * * P}<0.001$ was considered significantly different as compared to ME OT $(200 \mathrm{mg} / \mathrm{kg})$.

These readings were compared to the methanolic extract $(200 \mathrm{mg} / \mathrm{kg}$, p.o.) response to find out whether naloxone inhibits analgesic action of methanolic extract or not. The results showed that naloxone significantly inhibited the analgesic effects of methanolic extract (figure 2) which suggested that analgesic action of extract is possibly through opioid receptors.

\section{Effect on reaction time (in sec) in comparison to the pre treatment results}

Swiss albino mice of either sex weighing 20-30 g were divided in to 7 groups $(n=6)$ and placed on hot plate maintained at $55 \pm 0.2^{\circ} \mathrm{C}$. The reaction time i.e. jump response was recorded (in sec) prior treatment and 30,60, 120 and $150 \mathrm{~min}$ after treatment for each group. The statistical significance was determined in comparison to the pre treatment reaction time for each group as shown in Table 2.

Table 2: Effect of root extract on reaction time of mice using Hot-plate test.

\begin{tabular}{|l|c|c|c|c|c|}
\hline Group & \multicolumn{5}{|c|}{ Reaction time (in sec.) after } \\
\hline & Pretreatment & $\mathbf{3 0 ~} \mathrm{min}$ & $\mathbf{6 0} \mathrm{min}$ & $\mathbf{1 2 0} \mathbf{m i n}$ & $\mathbf{1 5 0} \mathbf{m i n}$ \\
\hline Group I & $1.31 \pm 0.35$ & $1.59 \pm 0.29$ & $1.34 \pm 0.30$ & $1.64 \pm 0.37$ & $1.46 \pm 0.27$ \\
\hline Group II & $1.55 \pm 0.27$ & $2.40 \pm 0.29$ & $5.05 \pm 0.60^{* * *}$ & $7.81 \pm 0.44^{* * *}$ & $8.25 \pm 1.12^{* * *}$ \\
\hline Group III & $1.63 \pm 0.31$ & $3.63 \pm 0.48^{*}$ & $6.56 \pm 1.27^{* * *}$ & $8.77 \pm 1.00^{* * *}$ & $9.52 \pm 1.4^{* * *}$ \\
\hline Group IV & $1.59 \pm 0.35$ & $5.44 \pm 0.51^{* * *}$ & $8.05 \pm 1.36^{* * *}$ & $9.75 \pm 0.59^{* * *}$ & $9.89 \pm 0.66^{* * *}$ \\
\hline Group V & $1.61 \pm 0.24$ & $3.10 \pm 0.69^{* *}$ & $4.73 \pm 0.88^{* * *}$ & $5.64 \pm 0.86^{* * *}$ & $5.88 \pm 0.67^{* * *}$ \\
\hline Group VI & $1.49 \pm 0.34$ & $3.79 \pm 0.23^{* * *}$ & $4.13 \pm 0.25^{* * *}$ & $5.39 \pm 0.36^{* * *}$ & $5.19 \pm 0.86^{* * *}$ \\
\hline Group VII & $1.16 \pm 0.22$ & $10.15 \pm 0.58^{* * *}$ & $7.75 \pm 0.61^{* * *}$ & $6.54 \pm 0.44^{* * *}$ & $4.91 \pm 0.34^{* * *}$ \\
\hline
\end{tabular}

Values are given as mean $\pm S D$ (sec.); $n=6$. Statistical differences were evaluated by ANOVA followed by Dunnett test. ${ }^{*} P<0.05,{ }^{* *} P<0.01$ and ${ }^{* * *} P<0.001$ as compared to control.

\section{DISCUSSION}

Pain is an unpleasant sensation, with a large subjective component. It is often accompanied by depression and a feeling of hopelessness. Acetic acid produces a painful reaction and acute inflammation in the peritoneal area. In acetic acid-induced abdominal writhing which is the visceral pain model, the processor releases arachidonic acid via cyclooxygenase, and prostaglandin biosynthesis plays a role in the nociceptive mechanism. ${ }^{15,16}$ In writhing test, the methanolic root extract of Operculina turpethum at the doses of 50, 100 and $200 \mathrm{mg} / \mathrm{kg}$, p.o. inhibited writhing on average by $9.49,53.45$ and $79.31 \%$ respectively, whereas aqueous extract (200mg/kg, i.p.) inhibited $53.89 \%$; aspirin $(100 \mathrm{mg} / \mathrm{kg}$, i.p.) inhibited $63.79 \%$ and pethidine $(25 \mathrm{mg} / \mathrm{kg}$, i.p.) inhibited $93.97 \%$ compared to control. These results support the hypothesis of participation of Operculina turpethum root extracts in the inhibition of prostaglandin synthesis. The result showed that methanolic extract at the dose of $200 \mathrm{mg} / \mathrm{kg}$ is more potent analgesic as compared to the same dose of aqueous extract and aspirin $(100 \mathrm{mg} / \mathrm{kg}$, i.p.). Phytochemical investigation showed that methanolic extract contains flavanoids in higher concentration as compared to aqueous extract and it is the flavonoids which contribute to the analgesic activity. ${ }^{17}$ The analgesic activity of methanolic extract $(200 \mathrm{mg} / \mathrm{kg}$, p.o.) is significantly decreased on concurrent administration of opioid receptor antagonist i.e. naloxone $(5 \mathrm{mg} / \mathrm{kg}$, i.p.). The studies revealed the possible involvements of opioid receptor in the analgesic action. 
Hot plate test was also used to characterize the analgesic activity of extract. The results showed that oral administration of both methanolic $(50,100$ and $200 \mathrm{mg} / \mathrm{kg}$, p.o. doses) and aqueous extract $(200 \mathrm{mg} / \mathrm{kg}$, p.o.) significantly and gradually raised the pain threshold at observation time 30, 60 and 120 min but increase slightly after $150 \mathrm{~min}$ in comparison to control. Both the extracts at the dose $200 \mathrm{mg} / \mathrm{kg}$, p.o. showed highest analgesic effect after $120 \mathrm{~min}$ of the oral administration but methanolic extract showed most potent analgesic effect as compared to aqueous extract in the same dose. Pethidine, used as a reference drug, also produced a significant analgesic effect during all the observation times when compared with control values. The hot plate test is considered to be selective for opioid-like compounds in several animal species, but other centrally acting drugs, including sedatives and muscle relaxants, have also shown activity in this test. ${ }^{14}$ Inhibition of analgesic effect of methanolic extract $(200 \mathrm{mg} / \mathrm{kg}$, p.o.) after administration of opioid receptor antagonist, naloxone (5mg/ $\mathrm{kg}$, i.p.), in group VIII showed involvement of opioid receptors.

As described above methanol extract $(200 \mathrm{mg} / \mathrm{kg}$, p.o.) showed significant analgesic effect in hot plate model $(P<0.001)$ and acetic acid-induced writhing model $(P<0.001)$. These observations tend to suggest that the methanolic extract possesses centrally and peripherally mediated analgesic properties. The peripheral analgesic effect of the root extract may be mediated via inhibition of cyclooxygenases and/or lipooxygenases (and other inflammatory mediators), while the central analgesic action of the extract may be mediated through opioid receptors or inhibition of central pain receptors or inhibition of prostaglandin endoperoxide synthase 1 gene-derived protein (i.e. COX-3). ${ }^{18,19,20}$

\section{CONCLUSION}

The findings of the present work indicate potential analgesic effect of the root extract of Operculina turpethum Linn. It was noted that methanolic root extract showed more potent analgesic activity as compared to the aqueous extract in the same dose $(200 \mathrm{mg} / \mathrm{kg}$, p.o.). The root extract of the plant was found to have both central and peripheral analgesic activities probably through opioid receptor and through suppression of synthesis of inflammatory mediators by inhibition of cyclooxygenases and/or lipoxygenases respectively. Thus the present work proved the traditional use of Operculina turpethum Linn. as analgesic.

\section{REFERENCES}

1. Khare CP. Indian herbal remedies: rational western therapy, Ayurvedic and other traditional usage. 1st ed. New York: Springer-Verlag Berlin Heidelberg, 2004, 338-339.

2. Khare CP. Encyclopedia of Indian medicinal plants rational western therapy, Ayurvedic and other traditional usage. 1st ed. New York: Springer-Verlag Berlin Heidelberg, 2004, 3-23.
3. Rasid MH, Gafur MA, Sadik MG, Aziz M, Rahman A. Antibacterial and cytotoxic activities of extracts and isolated compounds of Ipomoea turpethum. Pak. J. Biol. Sci. 5(5), 2002, 597-599.

4. Bhande RM, Laakshmayya Kumar P, Mahurkar NK, Setty SR. Pharmacological screening of root of Operculina turpethum and its formulations. Acta Pharm. Sci. 48(1), 2006, 11-17.

5. Ahmad R, Ahmad S, Khan NU, Hasnain A. Operculina turpethum attenuates $\mathrm{N}$ - nitrosodimethylamine induced toxic liver injury and clastogenicity in rats. Chem. Biol. Interact. 181(2), 2009, 145-153.

6. Pulipaka S, Challa SR, Pingili RB. Comperative antidiabetic activities of methanolic extract of Operculina turpethum stems and root against healthy and streptozotocin induced diabetic rats. Int. Curr. Pharm. 1(9), 2012, 272-278.

7. Shareef H, Rizwani GH, Watanabe N, Gilani AH. Studies on antidiarrhoeal, antispasmodic and bronchodilator activities of Operculina turpethum Linn. BMC Complement Altern. MED. 14(1), 2014, 479.

8. Onoja SO, Madubuike GK, Ezeja MI, Chukwu C. Investigation of the laxative activity of Operculina turpethum extract in mice. Int. J. Pharm. Clin. Res. 7(4), 2015, 275-279.

9. Tripathi KD. Essential of medical pharmacology. 7th ed. New Delhi: Jaypee Brother's medical publication Pvt. Ltd, 2015, 192-209.

10. Anbuselvam C, Vijayavel K, Balasubramanian MP. Protective effect of Operculina turpethum against 7, 12- dimethylbenz(a)anthracene induced oxidative stress with reference to breast cancer in experimental rats. Chem. Biol. Interact. 168(3), 2007, 229-236.

11. Kokate CK, Purohit AP, Gokhale SB. Pharmacognosy. 50th ed. Pune: Nilrali Prakashan, 2014, 13.139-146.

12. Collier HDJ, Dinnin LC, Johnson CA, Schneider C. The abdominal response and its suppression by analgesic drugs in the mouse. Br. J. Pharmacol. 32(2), 1968, 295310.

13. Hosseinzadeh $H$, Ramezani $M$, Salmani G. Antinociceptive, anti-inflammatory and acute toxic effects of Zataria multiflora Boiss extracts in mice and rats. J. Ethanopharmacol. 73(3), 2000, 379-385.

14. Hiruma-Lima CA, Gracioso JS, Bighetti EJB, Germonsen $R L$, Souza Brito ARM. The juice of fresh leaves of Boerhaavia diffusa L. (Nyctaginaceae) markedly reduces pain in mice. J. Ethnopharmacol. 71(1-2), 2000, 267-274.

15. Franzotti EM, Santos CV, Rodrigues HM, Mourao RH, Andrade MR, Antoniolli AR. Anti-inflammatory, analgesic activity and acute toxicity of Sida cordifolia $\mathrm{L}$. (Malva-branca). J. Ethnopharmacol. 72(1-2), 2000, 273-277. 
16. Duarte IDG, Nakamura M, Ferreira SH. Participation of the sympathetic system in acetic acid-induced writhing in mice. Braz. J. Med. Biol. Res. 21, 1988, 341-343.

17. Queiros AC, Lira DP, Dias TL M F, Souza ET, Matta CBB. The antinociceptive and anti-inflammatory activities of Piptadenia stipulacea Benth (Fabaceae). J. Ethnopharmacol. 128(2), 2010, 377-383.

18. Ballou L, Botting RM, Goorha S, Zhang J, Vane JR. Nociception in cyclooxygenase isozyme-deficient mice. Proc. Natl. Acad. Sci. U.S.A. 97(18), 2000, 10272-10276.
19. Dou W, Jiao Y, Goorha S, Raghow R, Ballou LR. Nociception and the differential expression of cyclooxygenase-1 (COX-1), the COX-1 variant retaining intron-1 (COX-1v), and COX-2 in mouse dorsal root ganglia (DRG). Prostag. Oth. Lipid M. 74(1-4), 2004, 2943.

20. Ojewole JAO. Antinociceptive, anti-inflammatory and antidiabetic properties of Hypoxis hemerocallidea Fisch. and C.A.Mey. (Hypoxidaceae) corm ['African Potato'] aqueous extract in mice and rats. J. Ethnopharmacol. 103(1), 2006, 126-134.

Source of Support: None declared.

Conflict of Interest: None declared.

For any question relates to this article, please reach us at: editor@globalresearchonline.net

New manuscripts for publication can be submitted at: submit@globalresearchonline.net and submit_ijpsrr@rediffmail.com 